\title{
COVID-19 Vaccine Development, Trials and Tribulations
}

\author{
Juny Sebastian', Mandyam Dhati Ravi², Tegginamat Pramod Kumar ${ }^{3, *}$ \\ ${ }^{1}$ Department of Pharmacy Practice, JSS College of Pharmacy, JSS Academy of Higher Education and Research, S S Nagara, Mysuru, \\ Karnataka, INDIA. \\ ${ }^{2}$ Department of Pediatrics, JSS Medical College and Hospital, JSS Academy of Higher Education and Research, S S Nagara, Mysuru, \\ INDIA. \\ ${ }^{3}$ Department of Pharmaceutics, JSS College of Pharmacy, JSS Academy of Higher Education and Research, S S Nagara, Mysuru, \\ Karnataka, INDIA.
}

\begin{abstract}
The coronavirus disease 19 (COVID-19) is a pandemic viral infection caused by severe acute respiratory syndrome coronavirus 2 (SARS-CoV-2). Currently, COVID-19 has affected 210 countries and territories around the world. But there is no clinically approved antiviral drug or vaccine against COVID-19. Governments, private manufactures, academic institutions and non-profit organizations are working hard at a breakneck pace to develop a vaccine for COVID-19. However, vaccine development is very lengthy and expensive process, typically takes many years to produce a licensed vaccine. Because of the high failure rates and cost factors, developers generally follow a linear development sequence with multiple pauses for analysis of data. But in view of the COVID-19 pandemic, development steps need to be executed parallel before confirming the outcome of the previous step. In the current review, we summarize the process involved in the COVID-19 vaccine development and its challenges.
\end{abstract}

Key words: Candidate Vaccine, Corona Virus, COVID-19 Vaccine, SARS-CoV-2, Vaccine Clinical Trial, Vaccine Development.

\section{BACKGROUND}

The coronavirus disease (COVID-19) is an infectious disease caused by the newly identified virus, SARS-CoV-2. The coronavirus family is known to cause illness in humans, from common cold to severe or even fatal diseases such as Middle East Respiratory Syndrome and Severe Acute Respiratory Syndrome (SARS). As COVID19 is pandemic and spreading globally, there is an increasing demand for vaccines, medicines, personal protection equipments and diagnostics kits and reagents. At this stage, no specific vaccine or treatment is available. ${ }^{1}$ The outbreak was declared on $30^{\text {th }}$ January 2020 as a Global public health emergency of international concern. However, many ongoing clinical trials are evaluating potential treatment options and vaccines. Normally, a candidate vaccine needs to go through pre-clinical stages as well as multicenter clinical trials involving populations across the globe to create large data to prove its efficacy and safety. ${ }^{1,2}$

\section{Stages of Vaccine Development}

Vaccines are one of the most cost-effective public health interventions and therefore, an essential component in the public health. Vaccines are very special as they promote health, protect individuals, communities and entire populations and saving lives rapidly thereby showing their positive impact. ${ }^{3}$ But the development of a new vaccine is a complex process and takes an average of 10-15 years to establish efficacy, safety and quality. ${ }^{4}$ According to Centre for Disease Control and prevention (CDC) of Dept. of Health and Human services, United States
Submission Date: 16-04-2020; Revision Date: 28-05-2020; Accepted Date: 02-07-2020

DOI: 10.5530/ijper.54.3s.144 Correspondence: Dr. Tegginamat Pramod Kumar

Principal and Professor, JSS College of Pharmacy, JSS Academy of Higher education and Research, Mysuru 570015, Karnataka, INDIA. Phone: +91 9900520875 E-mail: pramodkumar@ jssuni.edu.in

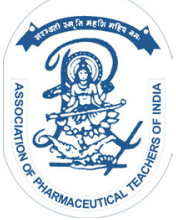

www.ijper.org 
of America (USA), there are six different stages for a vaccine development. ${ }^{5,6}$

1. Exploratory Stage: This is an intensive research phase and is designed to identify the natural or synthetic antigen that helps to treat or prevent a disease. The antigen might be live attenuated, killed or subunits of a particular virus/ bacteria.,

2. Pre- Clinical Stage: At this stage, the researchers use a cell culture or tissue culture systems and animal testing to determine the candidate vaccine's expected immunity. Many candidate vaccines fail at this stage because of inadequate immune response or safety issues..$^{5-7}$

3. Clinical Development Stage: During this Stage, the sponsor of the candidate vaccine submit an application to the regulatory agency of the particular country requesting permission to the conduct the testing in humans. This application is a summary of the findings such as animal study data and toxicity data, clinical protocols for studies to be conducted, manufacturing information, data of any prior human experiments (if any) and information about the investigators. Once the regulatory agency reviews this documents and grant permission, the candidate vaccine must undergo three phases of clinical testing in humans. Additionally, the institute that conducted the study needs an institutional ethical committee approval for conducting the study. ${ }^{5-7}$

Phase 1: At this stage, researchers test the candidate vaccine in a small group of healthy volunteers to determine whether the vaccine is safe and to determine how it works in the human body. This phase lasts for several months and approximately $70 \%$ of the drugs entering this phase move to the next phase of clinical trial. ${ }^{5-7}$

Phase 2: During this phase, hundreds of human subjects are enrolled with an aim to get more information on safety, immunogenicity, immunization schedule and dose size of the candidate vaccine. This phase lasts several months to two years and approximately $33 \%$ the candidate vaccines entering this phase move to the next Phase of the clinical trial. ${ }^{5-7}$

Phase 3: In this phase, thousands of human subjects are enrolled and it aims to measure the safety and effectiveness of the candidate vaccine. Average time taken for this phase of the clinical trial is 1-4 years and approximately $25-30 \%$ of the candidate vaccines entering this phase move to the next stage of the clinical trial..$^{5-7}$

4. Regulatory review and approval: Once the candidate vaccine successfully completes all the three clinical trial phases, the vaccine developer applies to the respective regulator agency to get an approval for manufacture and marketing of the candidate vaccine. ${ }^{5-7}$

5. Manufacturing: The approved manufacturing units provide proper infrastructures, personnel and equipment necessary to manufacture large quantities of vaccines. The vaccine manufacturers are required to demonstrate that each vaccine batch meets the regulatory requirements as per the tests specified by the respective national regulatory authority (NRA). At this stage, the NRA is also responsible for the release process of official vaccine lots, based on the information and data provided by the manufacturer and confirmatory tests. ${ }^{3,5-7}$

6. Quality Control: The marketing authorization holders must adhere to the policies and procedures that enable them to track whether the candidate vaccine is having anticipated performance. Post marketing safety studies (Phase 4 Clinical trials) are one way to understand the safety and efficacy of the marketed vaccine. Several thousands of people are enrolled and to try to get more safety information such as rare/very rare adverse events, delayed adverse events and adverse events while administering vaccine combinations..$^{5-7}$

National regulatory authority is responsible to ensure that the vaccines used within their country is of good quality, of known potency and safe. All these processes are very complex in vaccine development as the public trusts in vaccination programs are key to the success of any immunization programs. A highest standard is expected for any vaccines as the general public has low tolerance for vaccine related adverse events since vaccines are given to a healthy population for prophylaxis purpose compared with drugs which are used to treat sick people.,

There are many challenges existing for vaccine development. Vaccine trials often pose ethical concerns. There is a hike in the emergence of various infectious diseases and many vaccines are in pipeline, mostly in the area of Influenza, Malaria, Ebola, SARS and now COVID-19. Pharmaceutical companies are investing money on vaccine research and development by giving preference to vaccine candidates, which are profitable as the average cost involved in a vaccine development ranges from $\$ 600$ million to $\$ 1$ billion USD. This high cost hinders innovations in the area of biotechnology for vaccine development despite the need of the community. Delay in obtaining regulatory approval also greatly influences vaccine release, as the regulatory authority requires time to review the submitted data. ${ }^{8}$

Generally vaccine development follows a linear pattern of steps that are time consuming. Rapid development requires multiple steps to run in parallel without waiting 
for outcomes and therefore the risk of losing money on a failed vaccine is significantly higher. Additional problems occur with trials being conducted during a pandemic such as identifying sites or the ethical problems with placebo control. It would work well if there is an international funding system supporting development, large volume manufacture, fair allocation to high-risk populations and insulating private sector developers from significant financial problems. ${ }^{9}$ The difference between development of vaccines during traditional and outbreak paradigm are presented in Figure 1 (Source: Lurie N et al. Developing Covid-19 Vaccines at Pandemic Speed NEJM 2020)

\section{COVID-19 Vaccine Candidates}

Currently, in view of the ongoing pandemic of COVID19 , there is lot of interest in developing a vaccine for this disease. Three clinical trials (two from China (ChiCTR2000031781 and ChiCTR2000030906) and one from USA (NCT04283461) $\}$ are in clinical trials and 67 are in pre-clinical phase. A Phase 1 clinical trial evaluating an investigational vaccine (mRNA-1273) has begun at Kaiser Permanente Washington Health Research Institute in Seattle. Another vaccine INO4800 backed by the Bill and Melinda Gates foundation has also entered phase 1 trials in USA. A list of ongoing vaccine development studies is described in Table $1 .{ }^{10}$

Different vaccine types of Corona vaccines such as live attenuated coronavirus vaccine, inactivated coronavirus vaccine, $\mathrm{S}$ protein-based, vectored vaccines, DNA vaccines and combination vaccines against coronaviruses are in development. ${ }^{11-15}$

Live attenuated coronavirus vaccines: Attenuating or weakening the wild virus/ bacteria in a laboratory by repeated culturing develops live attenuated vaccine (LAV). The immune response following the administration of LAV is identical to that produced

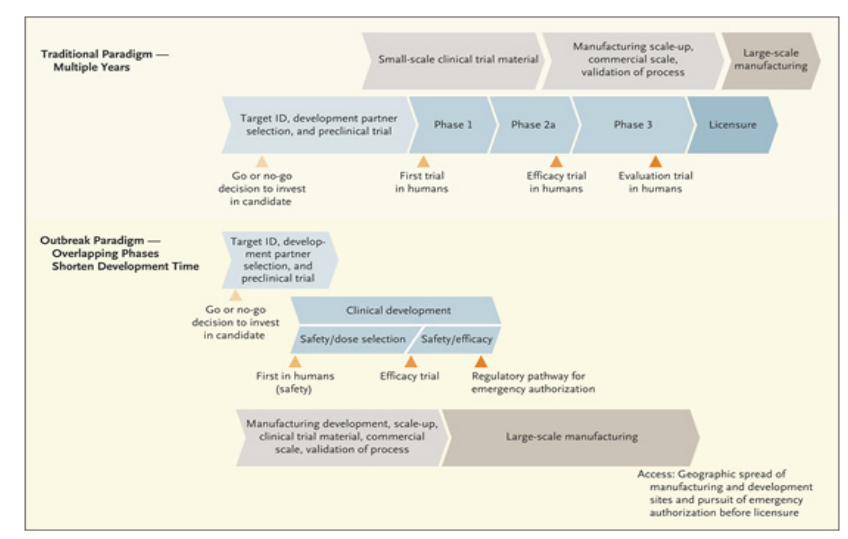

Figure 1: Vaccine development during traditional and outbreak Paradigm. by a natural infection. As of now, LAV of SARS-CoV are not developed, but the systems are developed to generate cDNA encoding the genomes of CoVs. ${ }^{11-15}$

Inactivated coronavirus vaccine: Inactivated vaccines are produced by growing bacteria or viruses in a culture medium and inactivating them using high temperature or chemicals such as formaldehyde. The development of inactivated vaccine requires high titers of specific infectious agent (in this case, SARS-CoV-2). This process needs extensive precautions and has some safety concerns especially for production workers. There is also a possibility of incomplete inactivation, which may be a potential public health threat. ${ }^{11-14}$

Sub Unit Vaccines: Subunit vaccines are developed by growing the whole organism in culture media and then further processing it to purify the components to be included in the vaccine. Subunit vaccines are categorized into three groups: protein-based, polysaccharide and conjugate vaccines. ${ }^{11-15}$

S Protein-based Coronavirus vaccine: Among all the structural proteins of the SARS-CoV-2, S- protein is the main antigenic component responsible for immune response in a host, neutralize antibodies and/or provide protection against infection. But these $\mathrm{S}$ protein-based vaccines may cause a harmful immune response, which may lead to liver damage raising safety concerns about the usage of this vaccine. ${ }^{11-15}$

Vectored vaccines against Coronavirus: Many research groups reported evaluation of vaccine utilizing other viruses as vectors for SARS-CoV proteins, including rabies virus, chimeric parainfluenza virus, vesicular stomatitis virus etc. results of vectored vaccines further demonstrate the induction of $\mathrm{S}$ protein-based Nabs are enough to confer protection. ${ }^{11-15}$

DNA vaccines against Coronavirus: Results of DNA vaccines for coronavirus demonstrated a strong immune response induction in animal models, specifically in mice. However, data on human subjects are limited. ${ }^{11-15}$

Combination vaccines: These are also evaluated for the ability to produce immune response to SARS-CoV-2 by administering two doses of $\mathrm{S}$ protein encoded DNA vaccine, followed by administration of inactivated whole cell virus. Results of the study showed more immunogenic response in mice than either type of vaccine alone. ${ }^{11-15}$

Geographical distribution of COVID-19 Vaccine Research and Development: As per Coalition for Epidemic Preparedness Innovations (CEPI) analysis, $46 \%$ of developers of active vaccine candidates are in North America, 18\% in China, 18\% in Asian countries excluding China and Australia and the remaining is in 
Table 1: List of COVID-19 candidate vaccines as on $11^{\text {th }}$ April 2020.10

\begin{tabular}{|c|c|c|c|}
\hline SI No & Platform & Type of candidate Vaccine & Developer \\
\hline \multicolumn{4}{|c|}{ Clinical development stage - Phase 1 and II } \\
\hline & $\begin{array}{c}\text { Non- Replicating Viral } \\
\text { Vector }\end{array}$ & Adenovirus Type 5 Vector & $\begin{array}{l}\text { CanSino Biological Inc. and Beijing } \\
\text { Institute of Biotechnology } \\
\text { (Phase } 2 \\
\text { ChiCTR2000031781 } \\
\text { Phase } 1 \\
\text { ChiCTR2000030906) }\end{array}$ \\
\hline & DNA & DNA plasmid vaccine Electroporation device & $\begin{array}{l}\text { Inovio Pharmaceuticals } \\
\text { (Phase } 1 \\
\text { NCT04336410) }\end{array}$ \\
\hline & RNA & LNP- encapsulated mRNA & $\begin{array}{l}\text { Moderna/NIAID } \\
\text { (NCT04283461) }\end{array}$ \\
\hline \multicolumn{4}{|c|}{ Preclinical development Stage } \\
\hline & DNA & DNA with electroporation & $\begin{array}{l}\text { Karolinska Institute / Cobra Biologics } \\
\text { (OPENCORONA Project) }\end{array}$ \\
\hline & DNA & DNA plasmid vaccine & Osaka University/ AnGes/ Takara Bio \\
\hline & DNA & DNA & Takis/Applied DNA Sciences/Evvivax \\
\hline & DNA & Plasmid DNA, Needle-Free Delivery & $\begin{array}{l}\text { Immunomic Therapeutics, Inc./EpiVax, } \\
\text { Inc./PharmaJet, Inc. }\end{array}$ \\
\hline & DNA & DNA plasmid vaccine & ZydusCadila \\
\hline & Inactivated & Inactivated + alum & Sinovac \\
\hline & Inactivated & Inactivated & $\begin{array}{l}\text { Beijing Institute of Biological Products/ } \\
\text { Wuhan Institute of Biological Products }\end{array}$ \\
\hline & Inactivated & TBD & Osaka University/ BIKEN/ NIBIOHN \\
\hline & Live Attenuated Virus & Deoptimized live attenuated vaccines & Codagenix/Serum Institute of India \\
\hline & $\begin{array}{l}\text { Non- Replicating Viral } \\
\text { Vector }\end{array}$ & ChAdOx1 & University of Oxford \\
\hline & $\begin{array}{l}\text { Non- Replicating Viral } \\
\text { Vector }\end{array}$ & MVA encoded VLP & GeoVax/BravoVax \\
\hline & $\begin{array}{l}\text { Non- Replicating Viral } \\
\text { Vector }\end{array}$ & Ad26 (alone or with MVA boost) & Janssen Pharmaceutical Companies \\
\hline & $\begin{array}{l}\text { Non- Replicating Viral } \\
\text { Vector }\end{array}$ & MVA-S encoded & $\begin{array}{c}\text { DZIF - German Center for Infection } \\
\text { Research }\end{array}$ \\
\hline & $\begin{array}{l}\text { Non- Replicating Viral } \\
\text { Vector }\end{array}$ & $\begin{array}{l}\text { Adenovirus- based NasoVAX expressing } \\
\text { SARS2-CoV spike protein }\end{array}$ & Altimmune \\
\hline & $\begin{array}{l}\text { Non- Replicating Viral } \\
\text { Vector }\end{array}$ & Ad5 S (GREVAXTM platform) & Greffex \\
\hline & $\begin{array}{l}\text { Non- Replicating Viral } \\
\text { Vecto }\end{array}$ & Oral Vaccine platform & Vaxart \\
\hline & $\begin{array}{l}\text { Non- Replicating Viral } \\
\text { Vector }\end{array}$ & MVA expressing structural proteins & $\begin{array}{l}\text { Centro Nacional Biotecnología (CNB- } \\
\text { CSIC), Spain }\end{array}$ \\
\hline & Protein Subunit & Capsid-like Particle & AdaptVac (PREVENT-nCoV consortium) \\
\hline & Protein Subunit & $\begin{array}{l}\text { Drosophila S2 insect cell expression system } \\
\text { VLPs }\end{array}$ & ExpreS2ion \\
\hline & Protein Subunit & $\begin{array}{l}\text { Peptide antigens formulated in lipid } \\
\text { nanoparticle formulation }\end{array}$ & IMV Inc \\
\hline & Protein Subunit & S protein & WRAIR/USAMRIID \\
\hline & Protein Subunit & S protein +Adjuvant & $\begin{array}{c}\text { National Institute of Infectious Disease, } \\
\text { Japan }\end{array}$ \\
\hline & Protein Subunit & VLP- recombinant protein + Adjuvant & $\begin{array}{l}\text { Osaka University/ BIKEN/ National } \\
\text { Institutes of Biomedical Innovation, } \\
\text { Japan }\end{array}$ \\
\hline
\end{tabular}




\begin{tabular}{|c|c|c|}
\hline Protein Subunit & $\begin{array}{l}\text { Native like Trimeric subunit Spike Protein } \\
\text { vaccine }\end{array}$ & $\begin{array}{c}\text { Clover Biopharmaceuticals Inc./GSK/ } \\
\text { Dynavax }\end{array}$ \\
\hline Protein Subunit & microneedle arrays $\mathrm{S} 1$ subunit & Univ. of Pittsburgh \\
\hline Protein Subunit & Peptide & Vaxil Bio \\
\hline Protein Subunit & Adjuvanted protein subunit (RBD) & Biological E Ltd \\
\hline Protein Subunit & Peptide & Flow Pharma Inc \\
\hline Protein Subunit & S protein & AJ Vaccines \\
\hline Protein Subunit & li-Key peptide & Generex/EpiVax \\
\hline Protein Subunit & S protein & EpiVax/Univ. of Georgia \\
\hline Protein Subunit & S protein (baculovirusproduction) & Sanofi Pasteur \\
\hline Protein Subunit & $\begin{array}{l}\text { VLP- recombinant protein nanoparticle vaccine } \\
\qquad+ \text { Matrix } M\end{array}$ & Novavax \\
\hline Protein Subunit & gp-96 backbone & Heat Biologics/Univ. Of Miami \\
\hline Protein Subunit & Molecular clamp stabilized Spike protein & University of Queensland/GSK/Dynavax \\
\hline Protein Subunit & $\mathrm{S} 1$ or RBD protein & Baylor College of Medicine \\
\hline Protein Subunit & Subunit protein, plant produced & iBio/CC-Pharming \\
\hline Protein Subunit & $\begin{array}{l}\text { Recombinant protein, nanoparticles (based on } \\
\text { S- protein and other epitopes) }\end{array}$ & $\begin{array}{l}\text { Saint-Petersburg scientific research } \\
\text { institute of vaccines and serums }\end{array}$ \\
\hline Protein Subunit & COVID-19 XWG-03 truncated S (spike) proteins & Innovax/Xiamen Univ./GSK \\
\hline Protein Subunit & Adjuvanted microsphere peptide & $\begin{array}{l}\text { VIDO-InterVac, University of } \\
\text { Saskatchewan }\end{array}$ \\
\hline Protein Subunit & $\begin{array}{l}\text { Synthetic Long Peptide Vaccine candidate for S } \\
\text { and M proteins }\end{array}$ & OncoGen \\
\hline Replicating Viral Vector & Measles Vector & ZydusCadila \\
\hline Replicating Viral Vector & Measles Vector & $\begin{array}{l}\text { Institute Pasteur/Themis/Univ. of } \\
\text { Pittsburg Center for Vaccine Research }\end{array}$ \\
\hline Live attenuated virus & Measles Virus (S, $\mathrm{N}$ targets) & $\begin{array}{c}\text { DZIF - German Center for Infection } \\
\text { Research }\end{array}$ \\
\hline Replicating Viral Vector & Horsepox vector expressing S protein & TonixPharma/Southern Research \\
\hline Replicating Viral Vector & $\begin{array}{l}\text { Live viral vectored vaccine based on attenuated } \\
\text { influenza virus backbone (intranasal) }\end{array}$ & BiOCAD and IEM \\
\hline Replicating Viral Vector & Influenza vector expressing RBD & University of Hong Kong \\
\hline Replicating Viral Vector & VSV vector expressing S protein & IAVI/Batavia \\
\hline RNA & $\begin{array}{l}\text { LNP- encapsulated mRNA cocktail encoding } \\
\text { VLP }\end{array}$ & $\begin{array}{l}\text { Fudan University/ Shanghai JiaoTong } \\
\text { University/RNACureBiopharma }\end{array}$ \\
\hline RNA & LNP- encapsulated mRNA encoding RBD & $\begin{array}{l}\text { Fudan University/ Shanghai JiaoTong } \\
\text { University/RNACureBiopharma }\end{array}$ \\
\hline RNA & $\begin{array}{c}\text { Replicating Defective SARS- CoV-2 derived } \\
\text { RNAs }\end{array}$ & $\begin{array}{l}\text { Centro Nacional Biotecnología (CNB- } \\
\text { CSIC), Spain }\end{array}$ \\
\hline RNA & LNP- encapsulated mRNA & University of Tokyo/ Daiichi-Sankyo \\
\hline RNA & Liposome- encapsulated mRNA & BIOCAD \\
\hline RNA & mRNA & China CDC/TongjiUniversity/Stermina \\
\hline RNA & mRNA & Arcturus/Duke-NUS \\
\hline RNA & mRNA & BioNTech/FosunPharma/Pfizer \\
\hline RNA & saRNA & Imperial College London \\
\hline RNA & mRNA & Curevac \\
\hline VLP & $\begin{array}{l}\text { Virus-like particle, based on RBD displayed on } \\
\text { virus-like particles }\end{array}$ & Saiba $\mathrm{GmbH}$ \\
\hline VLP & Plant-derived VLP & Medicago Inc. \\
\hline VLP & ADDomerTM multiepitope display & $\begin{array}{l}\text { Imophoron Ltd and Bristol University's } \\
\text { Max Planck Centre }\end{array}$ \\
\hline
\end{tabular}




\begin{tabular}{|l|l|l|c|}
\hline & Unknown & Unknown & ReiThera \\
\hline & Unknown & Unknown & BioNet Asia \\
\hline & Unknown & Unknown & MIGAL Galilee Research Institute \\
\hline & Unknown & Unknown & Doherty Institute \\
\hline & Unknown & Unknown & Tulane University \\
\hline
\end{tabular}

Europe. Developers of COVID-19 vaccine candidates are distributed across 19 countries. Which account for over three-quarters of the world population. No public information is available on the development of COVID-19 candidate vaccines in Latin America or African region. ${ }^{16}$

\section{World Health Organization (WHO) Prequalification} for vaccines: Candidate Vaccines that are procured by United Nations agencies and for financing by other agencies, including Global Alliance for Vaccines and Immunization (GAVI), require WHO Prequalification. The process of prequalification by WHO assures the quality, safety, efficacy and suitability of vaccine for immunization programs for low and middle-income countries. Hence, WHO encourage the vaccine developers and manufacturers to be aware of the process of prequalification even at the early stages of vaccine development. Licensure by the NRAs, or European Medicine Agency in case of Europe, is required prior to the consideration of prequalification process. ${ }^{17}$

\section{CONCLUSION}

Currently, the spread of COVID-19 has become a humanitarian and economic crisis. To tackle this crisis, it is very important for multiple professional expert groups from industry, regulators and other global bodies to work together to develop vaccines, get licensee to manufacture and reach population in need. However, considering the time taken for vaccine development, it is likely that no vaccine will be available for another year. Some vaccines were developed relatively rapidly such as the H1N1 vaccine but those for Ebola, Zika and SARS did not. The Ebola and Zika epidemics ended before the vaccine was developed and funding was stopped, causing financial losses to the manufacturers and setting back other vaccine development programs. Hence, researchers also stress the need of strong international coordination and co-operation among vaccine developers, regulators, funders, policy makers, public health authorities and governments to ensure the safe and effective manufacture of COVID-19 vaccine in sufficient quantities, which is accessible to the global community.

\section{ACKNOWLEDGEMENT}

Authors would like to thank JSS Academy of Higher Education and Research, Mysuru for their constant support and motivation in the completion of this article.

\section{CONFLICT OF INTEREST}

The authors declare that there is no conflict of interest.

\section{ABBREVIATIONS}

COVID-19: Coronavirus Disease 19; SARS-CoV-2: Severe Acute Respiratory Syndrome Coronavirus 2; SARS: Severe Acute Respiratory Syndrome; CDC: Centre for Disease Control and Prevention; USA: United States of America NRA: National Regulatory Authority (NRA); CEPI: Coalition for Epidemic Preparedness Innovations; LAV: Live Attenuated Vaccine; WHO: World health Organization; GAVI: Global Alliance for Vaccines and Immunization.

\section{REFERENCES}

1. Coronavirus. 2020. [cited 2020 Apr 5] Available from:https://www.who.int/ health-topics/coronavirus\#tab=tab_1

2. Coronavirus disease (COVID-19) Pandemic. 2020. [cited 2020 Apr 5] Available from: https://www.who.int/emergencies/diseases/novel-coronavirus-2019/ events-as-they-happen

3. Vaccine safety basics e- learning course. 2013. [Cited 2020 Apr 3] Available from: http://www.who.int/vaccine_safety/initiative/tech_support/ebasic/en/

4. The Complex Journey of a Vaccine: The Steps behind Developing a New Vaccine. 2020. [cited $2020 \mathrm{Apr}$ 3]. Available from:https://www.ifpma.org/wpcontent/uploads/2019/07/IFPMA-ComplexJourney-2019_FINAL.pdf

5. Vaccine testing and approval process. 2014. [cited 2020 Apr 4] Available from: https://www.cdc.gov/vaccines/basics/test-approve.html

6. The drug development process. 2018. [cited 2020 Apr 3]. Available from: https://www.fda.gov/patients/drug-development-process/step-3-clinicalresearch

7. The online MPH Program from Milken Institute School of Public Health at the George Washington University. 2019. [ cited 2020 April 3] Available from: https://publichealthonline.gwu.edu/blog/producing-prevention-the-complexdevelopment-of-vaccines/

8. Challenges and solution for conducting vaccine trials. 2020. [cited 2020 Apr 5]. Available from:https://www.crosnt.com/challenges-solutions-forconducting-vaccine-trials/

9. Lurie N, Saville M, Hatchett R, Halton J. Developing Covid-19 Vaccines at Pandemic Speed. The New England Journal of Medicine. 2020;1-5. DOI: 10.1056/NEJMp2005630

10. DRAFT landscape of COVID-19 candidate vaccines. 2020. [cited 2020 April 12] Available from https://www.who.int/blueprint/priority-diseases/key-action/ Novel_Coronavirus_Landscape_nCoV_11April2020.PDF 
11. Gillim-Ross L, Subbarao K. Emerging respiratory viruses: challenges and vaccine strategies. Clin Microbiol Rev. 2006;19(4):614-36.

12. Du L, He Y, Zhou Y, Liu S, Zheng BJ, Jiang S. The spike protein of SARSCoV - a target for vaccine and therapeutic development. Nat Rev Microbiol. 2009;7(3):226-36.

13. Jiang S, He Y, Liu S. SARS vaccine development. Emerg Infect Dis. 2005;11(7):1016-20.

14. Weingartl H, Czub M, Czub S, neufeld J, Marszal P, Gren J, et al. Immunization with modified vaccinia virus Ankara-based recombinant vaccine against severe acute respiratory syndrome is associated with enhanced hepatitis in ferrets. J Virol. 2004;78(22):12672-6.
15. Czub M, Weingartl H, Czub S, He R, Cao J. Evaluation of modified vaccine virus Ankara based recombinant SARS vaccine in ferrets. Vaccine. 2005;23(17-18):2273-9.

16. CEPI publishes analysis of COVID-19 vaccine development landscape. [internet] 2020 April 9 [cited 2020 April 15] Available from: https://cepi.net/ news_cepi/cepi-publishes-analysis-of-covid-19-vaccine-developmentlandscape/

17. WHO Target Product Profiles for COVID-19 Vaccines. 2020. [Cited 2020 April 15]. Available from: https://www.who.int/blueprint/priority-diseases/keyaction/WHO_Target_Product_Profiles_for_COVID-19_web.pdf?ua=1

Cite this article: Sebastian J, Ravi M, PramodKumar TM. COVID-19 Vaccine Development, Trials and Tribulations. Indian J of Pharmaceutical Education and Research. 2020;54(3s):s457-s463. 